\title{
Providing Insights into the Intended Curriculum of Probability for Basic Education Sector in Egypt from a Comparative Perspective
}

\author{
Samah Gamal Ahmed Elbehary $1,2^{\star}$ \\ ${ }^{1}$ PhD Student at Graduate School for International Development and Cooperation, Hiroshima University, JAPAN \\ ${ }^{2}$ Assistant Lecturer at Faculty of Education, Tanta University, EGYPT \\ *CORRESPONDENCE: $₫$ dr.samahelbe7ary@yahoo.com d184586@hiroshima-u.ac.jp
}

\begin{abstract}
In Egypt, the curricula delay in updating and stagnation behind modern educational trends represents a challenge, which may hinder education quality. Hence, to respond to such a national challenge, there is a need to review the curricula in light of modern educational trends, particularly in the case of probability where it has emerged as a mainstream strand in mathematics curricula worldwide. Moreover, according to the International Mathematics and Science Study 2003 and 2007, Egyptian students' achievement in "data and chance" is the lowest among other mathematics areas. Therefore, this study aims at providing insights into the intended curriculum of probability (ICOP) in Egypt from a comparative perspective with the New Zealand curriculum, which works as a model for curriculum development in other countries. The summative content analysis approach has been utilized to explore and quantify the primary probabilistic entities' usage in the official documents of both countries' curricula and ensure the consistency between them though assigning the fundamental probabilistic ideas. The study revealed that the ICoP in Egypt is consistent with the New Zealand curriculum in strengthening the probabilistic ideas that are relevant to randomness, events and sample space, and modeling and simulation. However, the ideas of independence and conditional probability, probability distribution and expectation, and convergence and the law of large numbers have not yet been considered in Egypt. Therefore, curriculum developers should look critically at these ideas and address them within teacher education programs. Moreover, explore how to enhance students' probabilistic reasoning represents an expected schema for further research.
\end{abstract}

Keywords: Sustainable Development Goals (SDGs), probability, Egyptian curriculum, New Zealand curriculum

\section{INTRODUCTION}

During the last few years, Egypt has strived to achieve political stability. The Cabinet has concentrated on formulating a long-term vision to develop a sustainable development strategy. As a result, Egypt has agreed to engage in the current global agenda entitled "Transforming our world: the 2030 Agenda for Sustainable Development" (Sustainable Development Strategy: Egypt Vision 2030, 2016).

One essential goal among sustainable development goals (SDGs), which has been contextualized within the local context under the pillar of education and training, is improving the educational system's quality to fit the international systems. Besides, developing curricula to cope with global developments and information

Article History: Received 10 October $2019 \bullet$ Revised 11 December $2019 \bullet$ Accepted 13 December 2019

(C) 2020 by the authors; licensee Modestum Ltd., UK. Open Access terms of the Creative Commons Attribution 4.0 International License (http://creativecommons.org/licenses/by/4.0/) apply. The license permits unrestricted use, distribution, and reproduction in any medium, on the condition that users give exact credit to the original author(s) and the source, provide a link to the Creative Commons license, and indicate if they made any changes. 
updates. Hence, the curricula delay in updating and stagnation behind modern educational trends represents a challenge, which may hinder education quality (Sustainable Development Strategy: Egypt Vision 2030, 2016). Therefore, to respond to such a national challenge there is a need to review the curricula in light of modern educational trends. This latter statement raises three basic inquiries: which content has a priority to review; which level of the curriculum (i.e., intended, implemented, and attained curriculum) could be focal; and how to provide insights into the Egyptian curriculum.

Although Egypt has not participated in the International Mathematics and Science Study (TIMSS) since 2007, within the next few years competing for TIMSS has been recognized as a national goal for the 2030 strategy. This means there is an emphasis on the international comparison, especially in mathematics and science. Considering that, the review of the Egyptian students' performance in TIMSS 2003 and 2007 revealed that their achievement in "data and chance" is the lowest among other mathematics content areas (Martin, 2005; Mullis, Martin, \& Foy, 2008). Besides this, very little research on statistics has been conducted in the Arab world (Innabi, 2014), which is also noticeable from the low participation of Arab scholars, particularly Egyptian researchers, in the international conferences of statistics education (e.g., International Conference on Teaching Statistics [ICOTS]).

Furthermore, within the school mathematics curriculum, probability is a fundamental idea that has been emerged as a mainstream strand, worldwide (Burrill \& Biehler, 2011; Jones, Langrall, \& Mooney, 2007). It also recognized as a crucial idea in school and out of school settings (Kazima, 2007; Nacarato \& Grando, 2014; Paul \& Hlanganipai, 2014). This importance of probability has been acknowledged by the Curriculum Center for Instructional Materials Development (CCIMD) that subordinates the Egyptian Ministry of Education and is responsible for developing pre-university curricula. According to CCIMD, the mathematics curriculum for the basic education sector is organized around five main content areas: numbers and operations; algebra, relationships, and functions; geometry; measurement; and statistics and probability. These content areas are explicitly included in each educational level, which means statistics and probability as a main content area within the mathematics school curriculum, start to be addressed from the $1^{\text {st }}$ grade. Later, in the $3^{\text {rd }}$ grade, students are confronted with probability, which is compulsory to learn continuously until the end of the lower secondary level (CCIMD, 2012).

Through analyzing the national school textbooks activities that are relevant to statistics units from grade 1 to 9 and exploring the correspondence between these activities' objectives and the seven fundamental statistical idea that should be addressed not only within the school curriculum but also within the teacher education program (Burrill \& Biehler, 2011); the number of activities assigned to each statistical idea was determined. As a result, it has been concluded that probability is a core statistical idea within the national school curriculum, wherein the majority of textbooks' activities intended to promote the probabilistic understanding for primary and lower secondary school students (see Figure 1). Therefore, the probability curriculum has been highlighted in the current study.

Moving to the second inquiry regarding the curriculum's level (i.e., probability curriculum), curriculum has been defined as the major organizing concept in considering how educational opportunities are provided to students (TIMSS \& PIRLS International Study Center, 2019). Further, the term opportunity refers to students encountering a potential experience in a classroom to study and learn about a particular topic (Houang \& Schmidt, 2008). According to the TIMSS framework, there are three levels of the curriculum; intended, implemented, and attained (Tri-Partite Model). The current study has concentrated on the intended curriculum of probability (ICoP), which represents the content that students are expected to learn as determined by countries' curriculum (Kurz, 2011; TIMSS \& PIRLS International Study Center, 2019). Hence, through reflecting on the ICoP, students' expected learning outcomes can be interpreted.

The earlier discussion needs to be strengthened by a theoretical perspective, which represents the answer for the third inquiry. Hence, two notions have been acknowledged and combined; the comparative perspective and the fundamental probabilistic ideas (Batanero, Chernoff, Engel, Lee, \& Sánchez, 2016; Heitele, 1975). While the former has been considered by comparing the ICoP in Egypt with the New Zealand curriculum (which works as a model and resource for curriculum and pedagogical changes in other countries (Forbes, 2014)), the latter provides key points to reflect the main content of probability that should be included at different educational levels (Batanero et al., 2016). Therefore, the ICoP in the Egyptian context can be investigated through identifying the embedded fundamental probabilistic ideas in the curriculum standards in comparison to the New Zealand curriculum. 


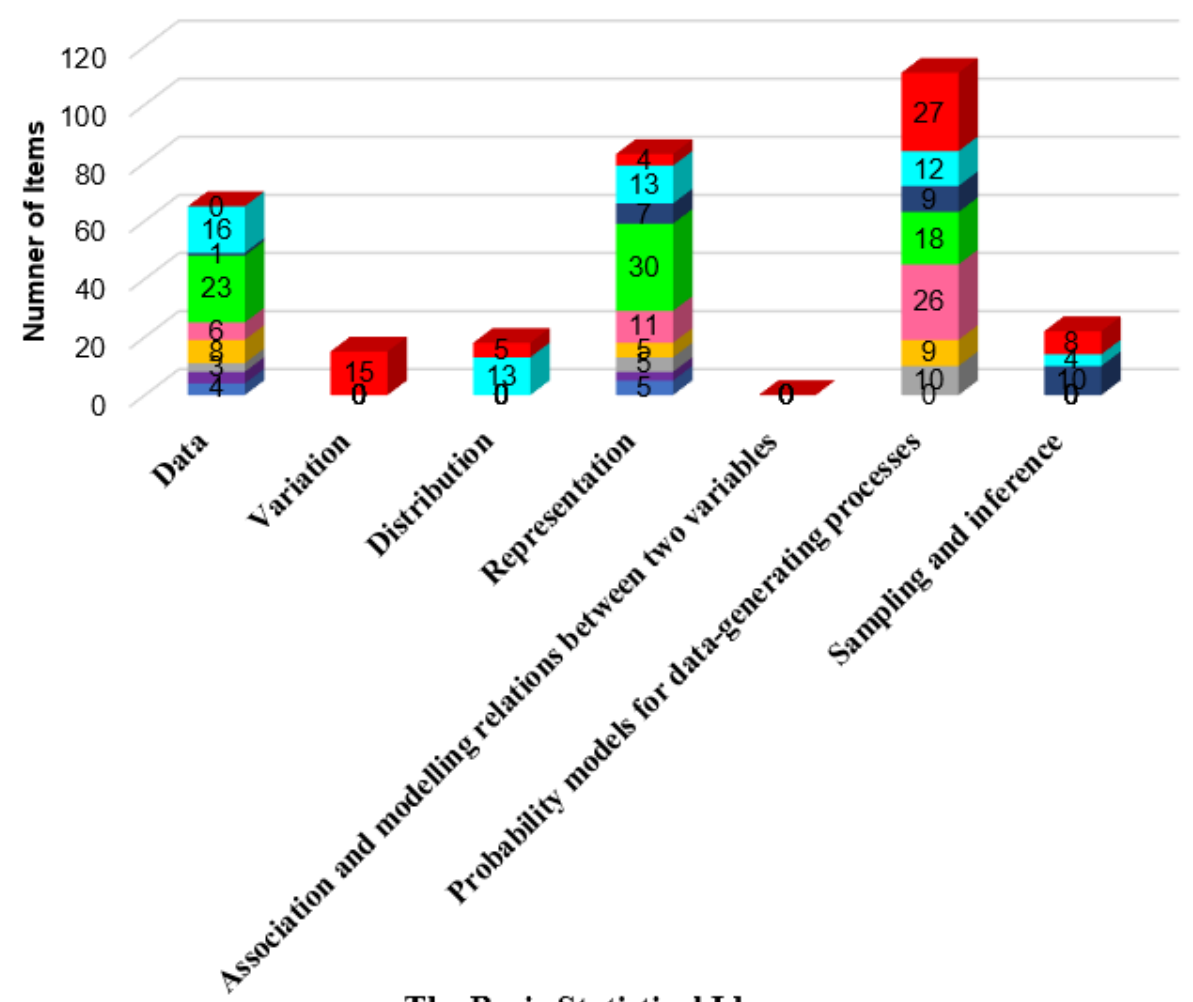

The Basic Statistical Ideas

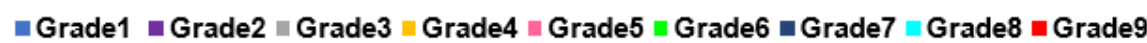

Figure 1. Distribution of fundamental statistical ideas within the national school textbook for the basic education sector

\section{THEORETICAL FRAMEWORK}

As noted earlier, the current study has been theorized in light of two essential points; the comparative perspective and the fundamental probabilistic ideas, which have been approached as follows;

\section{The Comparative Perspective with the New Zealand Curriculum}

Recently, the 2030 agenda for sustainable development has been adopted by United Nations member states since 2015 to provide a shared schema for peace and prosperity for people now and into the future. At the heart of this vision, there are 17 SDGs, which represent an urgent call for action by all countries, developed and developing, in a global partnership. Indeed, both Egypt and New Zealand are committed to achieving SDGs. As a result, the Egyptian national strategic plan 2030 has been formulated to be in line with SDGs. On the other hand, New Zealand has committed to play its part at home and abroad to achieve the SDGs (SDGs, 2019).

Through reflecting on one of the latest reports for SDGs (2019), it has been shown that Egypt's current ranking is 92 out of 162 . On the other side, New Zealand has achieved a high SDG global ranking of 11. Further, the two countries' average performance in fulfilling SDGs has been presented by the following figure;

Of the SDGs, the fourth goal focuses on quality education in a broad sense, which has been stated as "Ensure inclusive and equitable quality education and promote lifelong learning opportunities for all", in which there is an extent of global citizenship education at all levels (SDG, 2019). According to the current assessment of SDGs (2019), there is a stagnate to achieve the quality of education in Egypt. However, New Zealand is maintaining this achievement in the quality of education. 

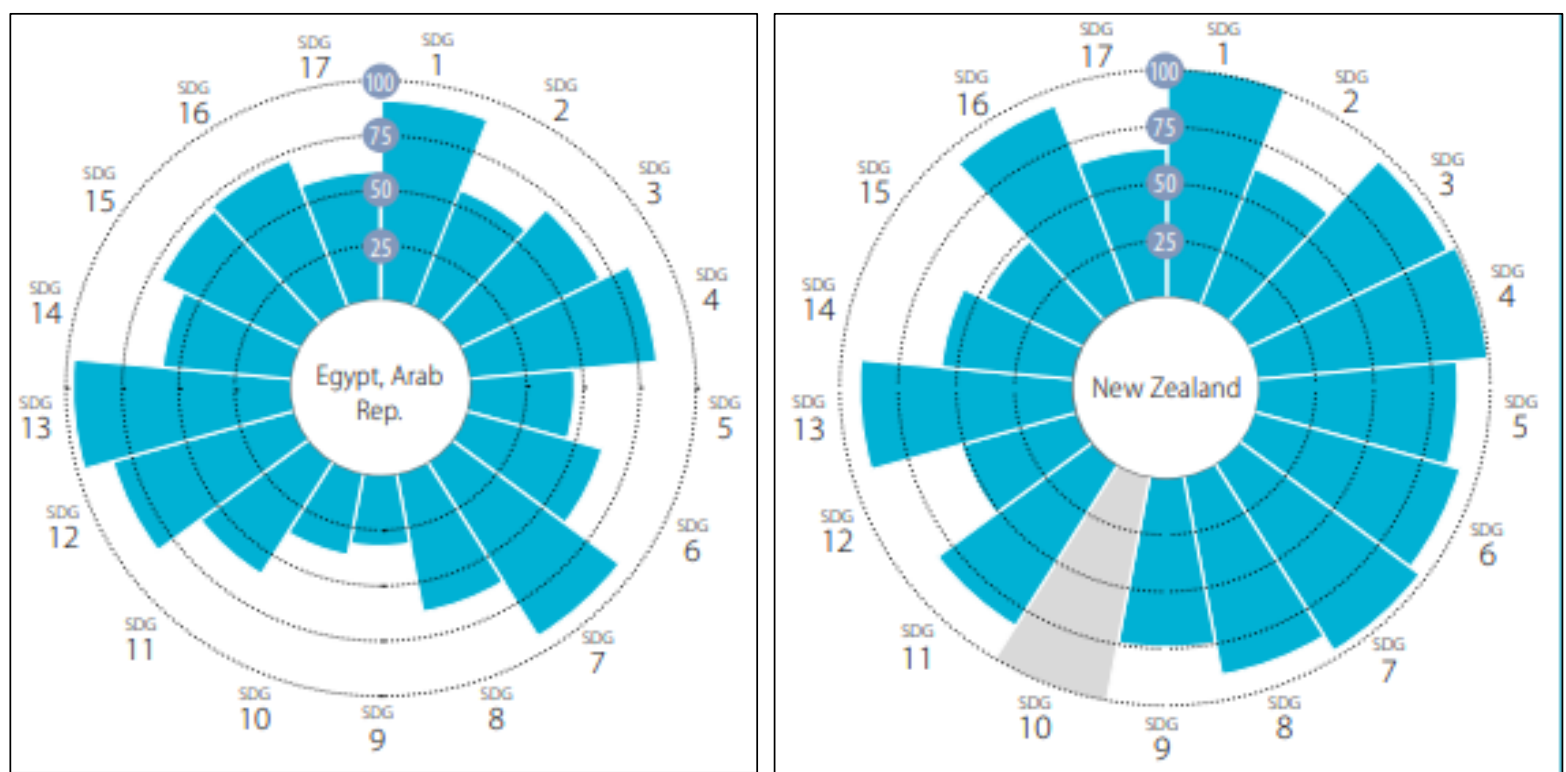

Figure 2. Average performance by SDGs in Egypt and New Zealand Source: SDGs Report, 2019, https://unstats.un.org/sdgs/report/2019/

From this perspective, the SDGs strategy works as a shared roadmap to achieve the educational goals more collectively in a global sense. Besides, it can be considered as the norm where the participated countries strive to achieve its goals. In particular the case of the intended curriculum that clarifies the intentional opportunities afforded to students for studying specific contents to achieve intended educational goals planned by governments or the educational community (Houang \& Schmidt, 2008).

Another specific reason for conducting the current comparison is that when the discussion is placed into the field of statistics education research, it is worthwhile to mention that the New Zealand curriculum has developed to the stage where it now serves as a working model for other countries to adapt to fit their particular circumstances. Therefore, the New Zealand curriculum can be used as a resource for curriculum and pedagogical changes in other countries (Forbes, 2014).

This significant status of the New Zealand statistics curriculum is reflected in the active participation of the New Zealanders' statistics scholars in international conferences. In contrast to the Egyptian educators who rarely participate in statistics education research conferences, believing that statistic and probability denote one sub-unit of school mathematics. For instance, by reviewing the contributed papers of the ICOTS that serves one of the most important events on the international statistics education calendar, it has been shown that during the ICOTS 8, 9, and 10 (held in 2010, 2014 and 2018); there is only one paper prepared by the Egyptian Professor Mina (2014), who suggested theoretical basis for the teacher education in statistics. Further, within the whole Arab community - including Egypt - only four papers have been provided (Abdelbasit, 2010; Alfaki \& Hijazi, 2018; Innabi, 2014; Mina, 2014) where the discussion has incorporated the topics of teaching statistics in another language; teacher education basis; status of statistics education in the Arab countries; and building the statistics capacity. On the other side and by taking into consideration the difference between the Egypt and New Zealand populations, there were a variety of topics (8 papers) that have been discussed through the New Zealand educators individually or through their collaboration with other researchers from different countries (Clark, 2010; David \& Brown, 2010; David, Seddon, Harlow, \& Brown, 2014; Edwards, 2014; Foster, 2018; Petty, 2010; Stern, Stirling, Dale, \& Stern, 2010; Wang \& Wu, 2010).

\section{The Fundamental Probabilistic Ideas}

The most decisive conceptual event of the twentieth century has been the discovery that the world is not deterministic (Hacking, 1990). The term Probabilistic Revolution signals a shift from a deterministic conception of reality, phrased in terms of universal laws of stern necessity, to one in which probabilistic ideas have become central (Kruger, Gigerenzer, \& Morgan,1987). Since students are surrounded by randomness in their personal and school lives, there is a need to be ready to make adequate decisions under uncertainty. This need has been recognized by the educational authorities in many countries, where probability is included in the curricula from primary to university level (Jones et al., 2007; Torres \& Contreras, 2014). However, 
including a topic in the curriculum does not automatically assure its correct teaching and learning (Batanero et al., 2016), especially in the case of probability where many challenges have been stated through literature and which may hinder students' understanding of probability. For instance, many researchers agree on the lack of teacher preparation to teach probability (Ainley \& Monteiro, 2008; Batanero, Godino, \& Roa, 2004; Pecky \& Gould, 2005). Another challenge is relevant to the textbooks, which sometimes present a too narrow view of probability and some of the stated definitions are incorrect (Batanero et al., 2004). Therefore, in the case of probability, it is necessary to investigate the school curriculum, as the most fundamental structure for educational experiences and the underlying "skeleton" that gives characteristic shape and direction to instruction in the educational systems (Houang \& Schmidt, 2008). Further, according to the TIMSS framework, three different levels of the curriculum could be investigated to comprehend the characteristics of probabilistic knowledge provided to students; intended, implemented, and attained curriculum.

Indeed, reflecting on the content of probability that should be included at different educational levels has been admitted as a key point in teaching probability (Batanero et al., 2016). In the Egyptian context, Elbehary (2019) concluded that the provided primary school content of probability intends to enhance students' deterministic reasoning through experiencing many probabilistic tasks from the classical and axiomatic perspective. Further to this, there is a lack of addressing the frequentist approach and the subjective meaning of probability that considered crucial concepts for promoting students' probabilistic reasoning. However, there is no clear discussion yet, to justify why such deficiencies of the school textbooks have been manifested. Based on that, to get an inclusive understanding of probability education in Egypt, there is a need to look into the ICoP. Additionally, although there are many previous studies from different theoretical perspectives and cultures have shown that students tend to hold certain misconceptions about probability that negatively impact their learning (Borovcnik, 2008; Chiesi \& Primi, 2009; Jones et al., 2007; Rubel, 2007; Sharma, 2014; Zazkis \& Chernoff, 2008), there is a lack of research which reflected the role of the curriculum in shaping such problems, in particular from a comparative perspective.

Therefore, the current study aims to tackle this arena by employing a comparative perspective. Furthermore, to make the comparison more precise and operational, the study has focused primarily on Batanero et al.'s (2016) identification of the fundamental probabilistic ideas that have been adapted based on Heitele (1975); Batanero, Biehler, Maxara, Engel, and Vogel (2005a); and Batanero, Henry, and Parzysz (2005b). These ideas comprise randomness, events and sample space, combinatorial enumeration and counting, independence and conditional probability, probability distribution and expectation, convergence and the law of large numbers, sampling and sampling distribution, and modeling and simulation.

\section{RESEARCH QUESTION AND HYPOTHESIS}

Taking into consideration the comparative perspective with the New Zealand curriculum, and the fundamental probabilistic ideas, this research aims at providing insights into the ICoP for the basic education sector in Egypt. Therefore, the following central question has been addressed;

\section{Q: To what extent is the ICoP in Egypt consistent with the New Zealand curriculum?}

Moreover, this study has been formulated in the light of the following hypothesis;

Because New Zealand has achieved a high SDG global ranking of 11 compared to Egypt with a current rank of 92 out of 162, and the statistics curriculum in New Zealand has been developed to the stage where it now serves as a working model for other countries to adapt to fit their particular circumstances. It has been assumed that reflecting on the Egyptian ICoP from the perspective of the New Zealand curriculum can provide meaningful results, in such a way of impacting the curriculum reform in Egypt.

\section{RESEARCH METHOD}

\section{Research Design}

The current study has employed the qualitative content analysis which signifies one of the various research methods used to analyze text data, and it focuses on the characteristics of language as communication with attention to the content or contextual meaning of the text (Hsieh \& Shannon, 2005; McTavish \& Pirro,1990; Tesch,1990). In general, the goal of the content analysis is providing knowledge and understanding of the phenomenon under study (Downe-Wamboldt, 1992), wherein the phenomenon here (in this study) refers to the ICoP in Egypt. More precisely, the "summative content analysis" has been employed to answer the 
research question. The summative content analysis starts with identifying and quantifying certain words in a text to understand the contextual use of these words, where this quantification intends to explore the words' usage (Hsieh \& Shannon, 2005).

\section{Procedures and Data Analysis Processes}

In light of the qualitative content analysis processes, the following procedures have been operated (Hsieh \& Shannon, 2005; Kaid, 1989):

- Formulating the research question to be answered;

As stated earlier, this research attempts to provide insights into the ICoP for the basic education sector in Egypt from a comparative perspective with the New Zealand curriculum.

- Selecting the sample to be analyzed;

The ICoP in Egypt and New Zealand has been figured out through their official websites (CCIMD, 2012; The New Zealand Curriculum, 2007). It is formulated as learning standards, which describes the expected content for students to learn. For instance, $5^{\text {th }}$ grade students are expected to calculate the probability of the complementary event, according to the ICoP in Egypt. On the other side, based on the New Zealand curriculum, they are expected to compare and describe the variation between theoretical and experimental distributions in situations that involve elements of chance.

\section{- Defining the categories to be applied and outlining the coding process}

According to Folger, Hewes, and Poole (1984), the development of a good coding scheme is central to trustworthiness in research using content analysis. Hence, to ensure the results' trustworthiness, the analysis process started with defining the categories to be applied through the onto-semiotic approach.

The onto-semiotic approach is a semiotic analysis developed by Godino and collaborators (Godino, Batanero, \& Font, 2007). It uses the theoretical constructs of semiotics as the ontology of mathematical objects to understand mathematics and deals with the objects' meaning from an institutional or personal point of view. Accordingly, the onto-semiotic approach has been utilized to identify the primary entities of probability (as the units of analysis) in both Egypt and New Zealand's official documents which outline the ICoP, wherein these documents represent the institutional level (a group of people that share tools, rules, and actions). This approach defines the primary entities of probability as follows; probabilistic situations (problems or tasks) where the probabilistic object is used; language (concepts, terms, or notations) that are implicitly or explicitly employed in a probabilistic situation; procedures (operations, algorithms, or techniques) applied to manipulate the situation; and propositions (properties or attributes of the concepts) (Torres \& Contreras, 2014).

After identifying the primary entities of probability in both countries' curriculum, these entities have been assigned to the fundamental probabilistic ideas to understand the consistency between the ICoP in Egypt corresponding to the New Zealand curriculum.

\section{- Implementing the coding process and determining the trustworthiness}

Based on the previously stated definitions for the primary entities of probability, the official documents of both countries have been reviewed and coded, from grades 1 to 9 in the Egyptian context corresponded to 1 to 8 in New Zealand. Furthermore, since within the summative content analysis method, data analysis begins with searches for occurrences of the identified words by hand or by computer, then word frequency counts for each identified term are calculated (Hsieh \& Shannon, 2005). Hence, the frequencies of each entity (e.g., situations or language) have been calculated for each curriculum.

While the definitions of the primary entities of probability have guided the coding process, this process represents a deductive content analysis. Besides, to ensure the trustworthiness when the deductive approach is used, double coding often helps to assess the quality of categorization (Elo, Kääriäinen, Kanste, Pölkki, Utriainen, \& Kyngäs, 2014). Therefore, to guarantee the trustworthiness of the current study results, two rounds of the coding process have been employed in a time difference of two months (Schreier, 2012). As a result, the identified entities of probability itself and its frequencies were almost similar.

- Analyzing the results of the coding process.

The last step for the qualitative content analysis is analyzing the results of the coding process, which has been described in the next section (see the results and discussion section). 


\section{RESULTS AND DISCUSSION}

After implementing the processes of summative content analysis approach (as mentioned in the research method section); the results of the coding process have been labeled as follows;

\section{First; The Status of Probability within the School Mathematics Curriculum in Egypt Compared to New Zealand}

Probability has been embedded within the school mathematics in both countries' curricula. However, the name of the domain itself in which probability has assigned is slightly different; statistics and probability in Egypt versus statistics in the New Zealand curriculum. This situation can be interpreted in terms of Steinbring's (1991) criticism regarding the tendency to organize teaching probability and statistics within a hierarchical structure, rather than emphasizing the complementarity between the mathematical description and empirical application in stochastic situations. Hence, defining the domain by statistics and probability strengthens perceiving them as two different areas. As stated by Kazak and Confrey (2006), in such a traditional approach, the conceptual link between probability and statistics is not available until the discussion of statistical inference.

\begin{tabular}{|c|c|c|}
\hline \multicolumn{3}{|c|}{ Intended learning objectives of "statistics" in New Zealand } \\
\hline $\begin{array}{c}\text { Statistical } \\
\text { investigation }\end{array}$ & $\begin{array}{c}\text { Probability } \\
\text { investigate situations that } \\
\text { involve elements of chance. }\end{array}$ \\
\hline $\begin{array}{c}\text { Pose statistical questions and } \\
\text { try to answer it through } \\
\text { collecting the appropriate data, } \\
\text { organizing and representing it. }\end{array}$ & $\begin{array}{c}\text { Choose and apply the } \\
\text { appropriate statistical } \\
\text { methods and techniques to } \\
\text { describe the data, } \\
\text { summarizing, and } \\
\text { representing it. }\end{array}$ & $\begin{array}{c}\text { Understand the basic } \\
\text { probabilistic concepts and } \\
\text { use it to solve problems }\end{array}$ \\
\hline \multicolumn{2}{|c|}{ Intended learning objectives of "statistics and probability" in Egypt } \\
\hline \multicolumn{2}{|c}{} \\
\hline
\end{tabular}

Figure 3. Probability within the domain of statistics in Egypt and New Zealand

Figure 3 outlines how probability has been embedded within the domain of statistics and probability, and statistics in Egypt and New Zealand, respectively.

From Figure 3, generally speaking, the intended learning objectives of statistics in Egypt align with the New Zealand curriculum, in which almost all of the approved standards in the Egyptian context can be interpreted within the three main areas of statistics in the New Zealand curriculum (i.e., statistical investigation, statistical literacy, and probability). More precisely, concerning probability, it has been affirmed to be equal to the other two standards; statistical investigation and statistical literacy.

In the long term, this situation may positively affect the students' learning (i.e., attained curriculum). Since, emphasizing or disregarding an idea within the intended curriculum that includes goals and expectations set by the policymakers and curriculum developers, may affect teachers' interpretation of this curriculum. Besides, interpreting the curriculum is an essential role for teachers (Thijs \& Akker, 2009). Consequently, the more a statistical idea has been emphasized within the intended curriculum, the more teachers may believe in the importance of that idea, wherein teachers' beliefs influence their teaching practices and students' performance (Beswick, 2007; Polly et al., 2013; Stein \& Kim, 2008).

On the contrary, although the intended curriculum should align with the implemented curriculum for achieving the curriculum goals through the attained curriculum (Phaeton \& Stears, 2017). A critical issue has arisen in the Egyptian context, in which there is a mismatch between the status of probability within the intended learning objectives of statistics, and the implemented activities of the national school textbooks. As presented earlier in Figure 1, the majority of national school textbooks' activities have been allocated to 
probability, which indicates the importance of learning probability compared to both statistical literacy and statistical investigation in the implemented curriculum. However, the intended curriculum shows an equal affirmation (see Figure 3).

\section{Second: The Primary Probabilistic Entities within the ICoP in Egypt and New Zealand}

Through utilizing the OSA, the primary probabilistic entities within the ICoP in Egypt and New Zealand have been identified. Further, its frequencies have been calculated and are represented by Figures 4-7.

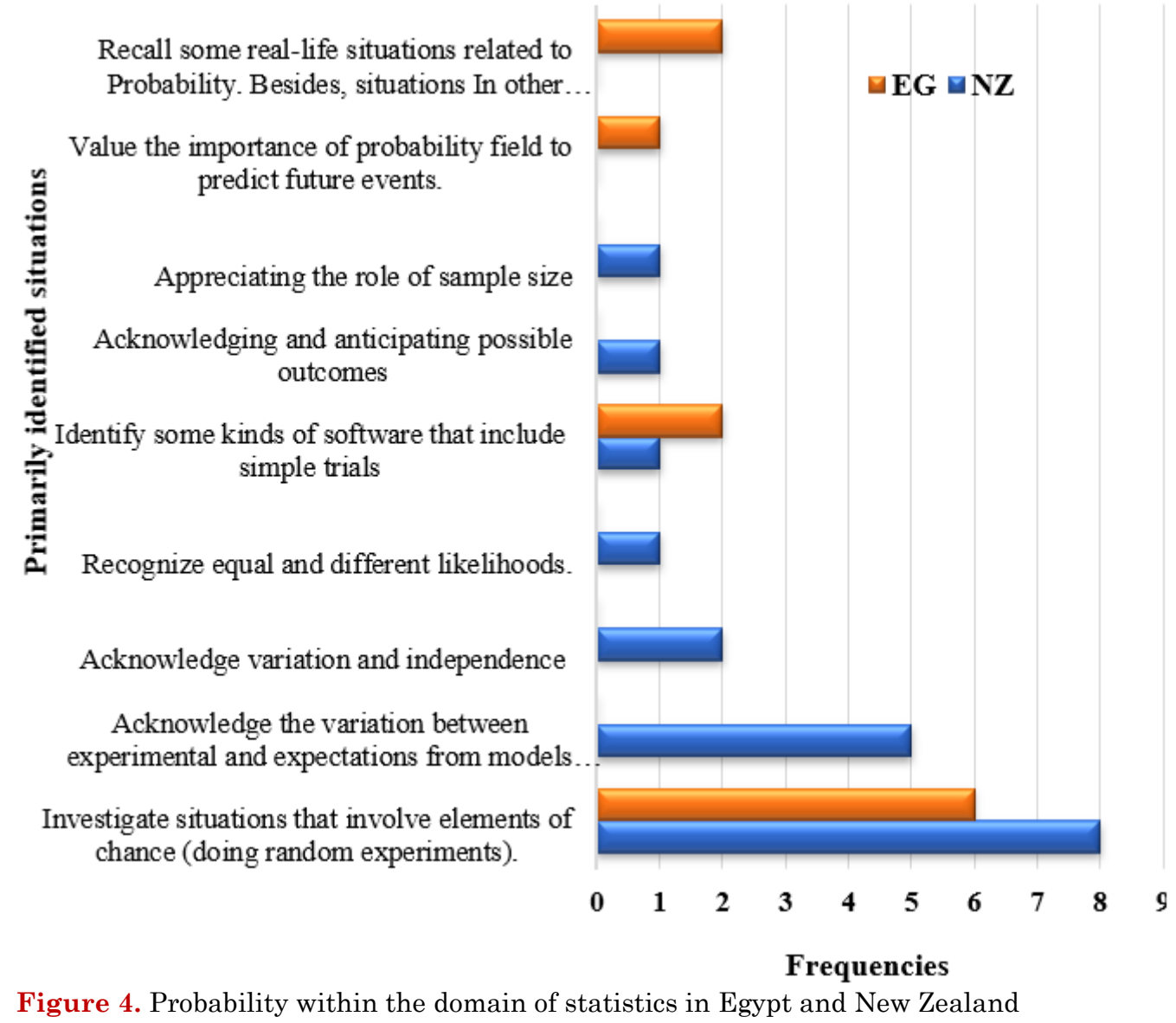

Figure 4. Probability within the domain of statistics in Egypt and New Zealand 


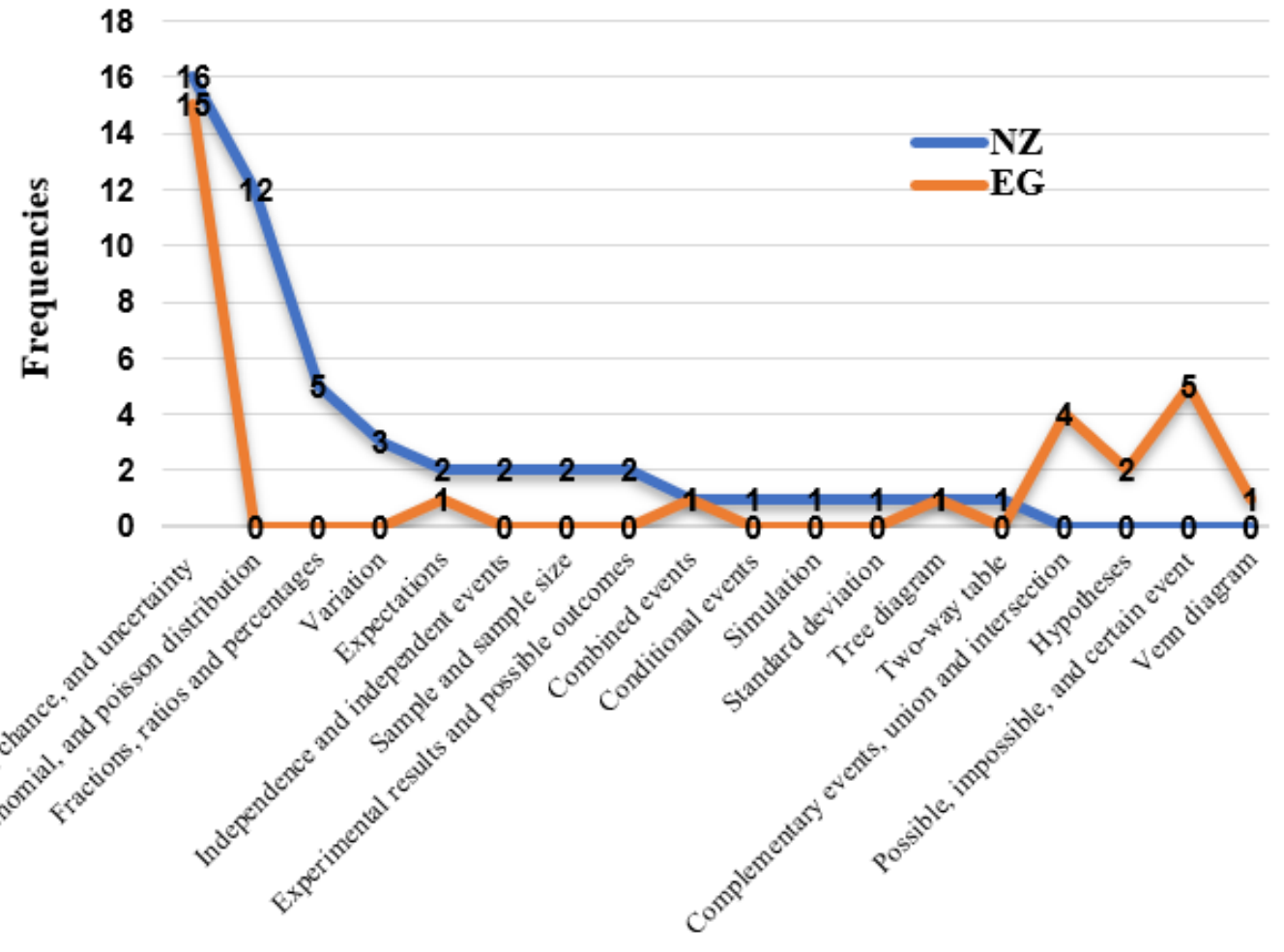

Primarily identified terms

Figure 5. Probability within the domain of statistics in Egypt and New Zealand

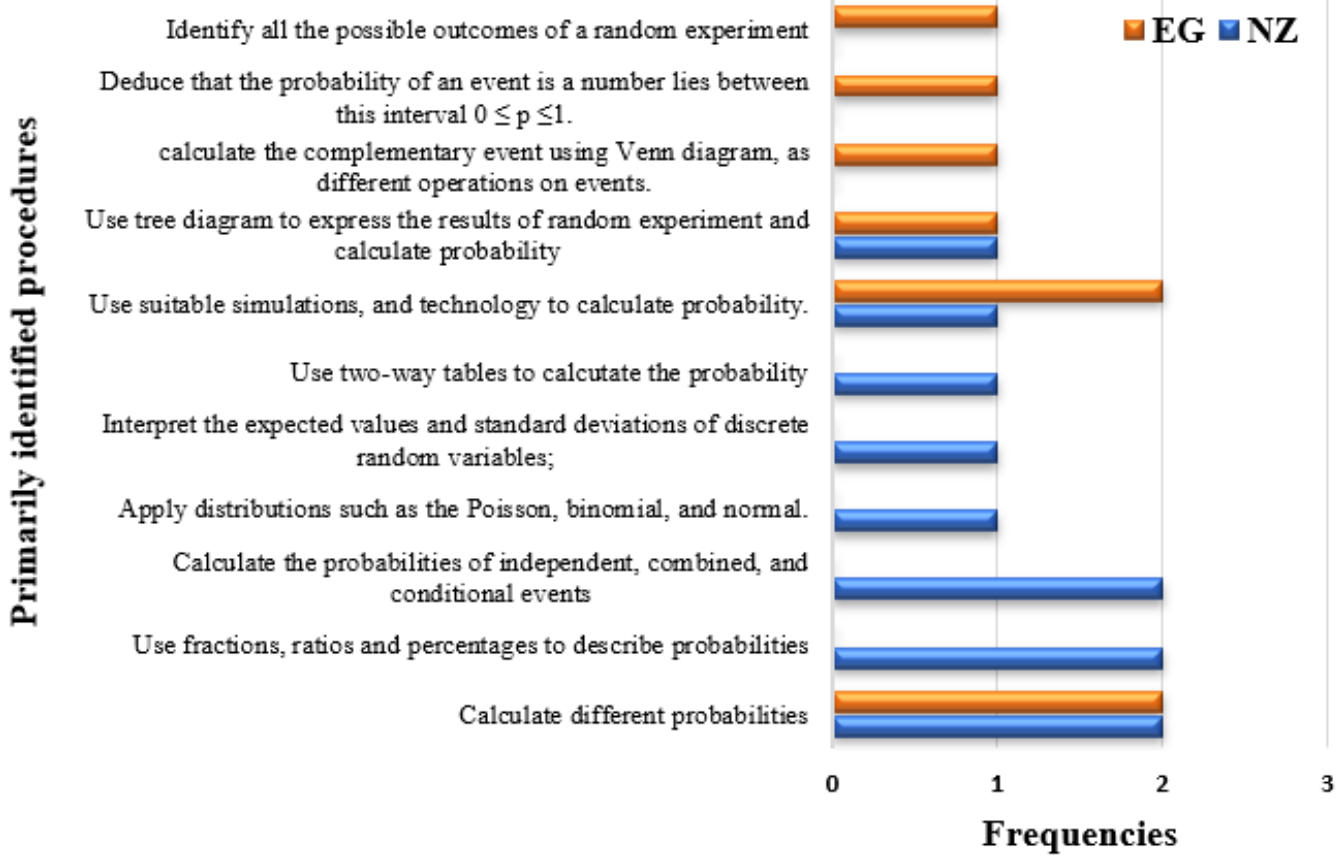

Figure 6. Probability within the domain of statistics in Egypt and New Zealand 


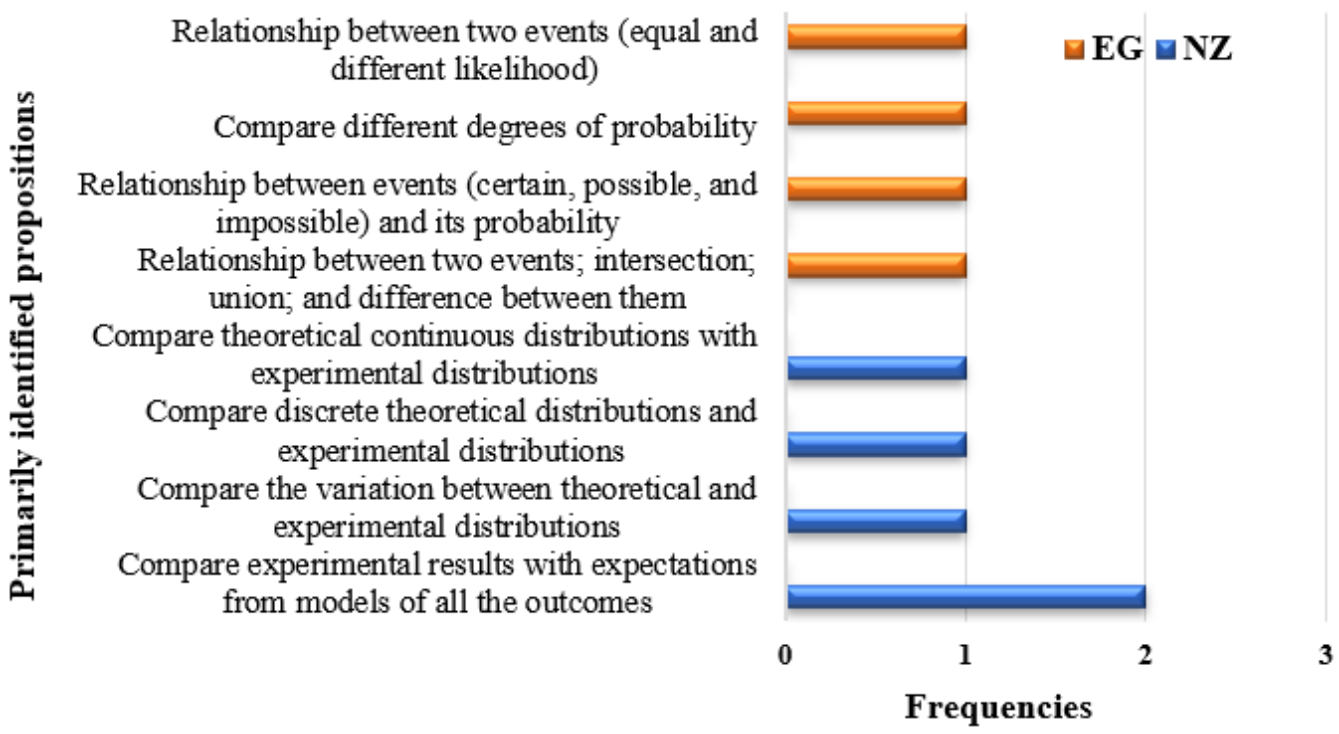

Figure 7. Probability within the domain of statistics in Egypt and New Zealand

Figures 4-7 provide detailed information regarding the primary probabilistic entities in both countries' curricula, in comparison to each other. As mentioned earlier (see research method section), to precisely discuss the extent of consistency between the ICoP in Egypt and New Zealand, in such way that enables to deduce the neglected ideas within the Egyptian context and give concrete implications, the emphasized probabilistic entities (i.e., the highest frequencies) in both countries' curricula have been highlighted and assigned to the fundamental probabilistic ideas. Hence, the results have been summarized in Table 1, taking into consideration that the dark color cells refer to the probabilistic entities that emphasized within both contexts. On the other side, if the probabilistic idea has been emphasized within one context, normal and italic letters used to indicate the Egyptian and New Zealand context, respectively.

Table 1. The correspondence between the primary entities of probability in both Egypt and New Zealand (NZ) curricula, and the fundamental probabilistic ideas

\begin{tabular}{|c|c|c|c|c|}
\hline & Situations & Language & Procedures & Propositions \\
\hline Randomness & $\begin{array}{l}\text { Investigate situations } \\
\text { that involve elements of } \\
\text { chance (both) }\end{array}$ & $\begin{array}{l}\text { Probability, likelihood, } \\
\text { chance, and uncertainty } \\
\text { (both) }\end{array}$ & & \\
\hline & & $\begin{array}{l}\text { Fractions, ratios and } \\
\text { percentages }(N Z)\end{array}$ & $\begin{array}{l}\text { Calculate the probability of } \\
\text { an event (both) }\end{array}$ & $\begin{array}{c}\text { Relationship between two } \\
\text { events (Egypt) }\end{array}$ \\
\hline $\begin{array}{c}\text { Events and } \\
\text { sample space }\end{array}$ & & $\begin{array}{c}\text { Possible, impossible, } \\
\text { and certain events } \\
\text { (Egypt) }\end{array}$ & $\begin{array}{c}\text { Use fractions, ratios and } \\
\text { percentages to describe the } \\
\text { probability }(\mathrm{NZ})\end{array}$ & $\begin{array}{l}\text { Relationship between the event } \\
\text { (certain, possible, impossible) } \\
\text { and its probability (Egypt) }\end{array}$ \\
\hline \multicolumn{5}{|l|}{$\begin{array}{c}\text { Combinatorial } \\
\text { enumeration and } \\
\text { counting }\end{array}$} \\
\hline $\begin{array}{c}\text { Independence } \\
\text { and conditional } \\
\text { probability }\end{array}$ & $\begin{array}{l}\text { Acknowledge variation } \\
\text { and independence (NZ) }\end{array}$ & & $\begin{array}{c}\text { Calculate the probability of } \\
\text { independent, combined, and } \\
\text { conditional events }(N Z)\end{array}$ & \\
\hline $\begin{array}{l}\text { Probability } \\
\text { distribution and } \\
\text { expectation }\end{array}$ & & $\begin{array}{c}\text { Theoretical, Normal, } \\
\text { Binomial, Poisson, and } \\
\text { Experimental } \\
\text { distribution (NZ) }\end{array}$ & & $\begin{array}{c}\text { Compare the variation between } \\
\text { theoretical and experimental } \\
\text { distributions (NZ) }\end{array}$ \\
\hline $\begin{array}{c}\text { Convergence and } \\
\text { law of large } \\
\text { numbers }\end{array}$ & $\begin{array}{l}\text { Acknowledge the } \\
\text { variation between } \\
\text { experimental and } \\
\text { expectations (NZ) }\end{array}$ & & & $\begin{array}{c}\text { Comparing experimental results } \\
\text { with expectations from models } \\
\text { of all the outcomes }(\mathrm{NZ})\end{array}$ \\
\hline \multicolumn{5}{|l|}{$\begin{array}{l}\text { Sampling and } \\
\text { sampling } \\
\text { distribution } \\
\end{array}$} \\
\hline $\begin{array}{l}\text { Modeling and } \\
\text { simulation }\end{array}$ & $\begin{array}{l}\text { Identify some kinds of } \\
\text { software that include } \\
\text { simple trials (both) }\end{array}$ & & $\begin{array}{l}\text { Use suitable simulations to } \\
\text { calculate probability (both) }\end{array}$ & \\
\hline
\end{tabular}


These results indicate, on the one hand, the ICoP in Egypt is consistent with the New Zealand curriculum in strengthening the probabilistic ideas that are relevant to randomness, events and sample space, and modeling and simulation, because these ideas are highlighted within both contexts. On the other hand, three other fundamental probabilistic ideas have been discussed within the New Zealand curriculum, but not yet considered in Egypt; independence and conditional probability, probability distribution and expectation, and convergence and law of large numbers. Consequently, the later three ideas denote neglected areas within the ICoP in the Egyptian context in comparison to New Zealand, wherein they have been highlighted within probability education literature as significant notions for students to learn, as follows;

"Independence and conditional probability" were included by Heitele (1975) in his list of fundamental stochastic ideas that helped probability theory to develop throughout history. Furthermore, prominent curriculum documents such as the National Council of Teachers of Mathematics standards (2000) and Guidelines for Assessment and Instruction in Statistics Education (American Statistical Association, 2007) recommended that students should understand the concepts of conditional probability and independent events before leaving high school. Hence, according to Borovenik and Kapadia (2009), these ideas should not be left out of any standard course in probability at school and university and in particular, the conditional probability that helps in making accurate inferences in everyday life. Despite this, the ICoP for the basic education sector in Egypt seems to disregard these concepts. Further, this condition has been stated before by Carranza and Kuzniak (2008) who noted that the school curriculum seems to ignore the subjective probability, which is widely used in the applications of statistics.

Regarding both ideas "probability distribution and expectation" and "convergence and law of large numbers" which mostly discussed together as they complement each other, Martignon (2014) noted that probability models, such as the binomial or normal distribution, supply us with the means to structure reality; they constitute important tools to recognize and to solve problems. Such a process of modeling random situations is an important step in any application of probability to real-world phenomena (Chaput, Girard, \& Henry, 2011). In such discussion, wherein our expectation about real phenomena may not be consistent with the empirical results, understanding the law of large numbers and the concept of convergence is essential. The law of large numbers is the probabilistic idea that connects two big theories of probability; classical and experimental. It implies the mathematical tool to interpret the empirical results as compared to the calculated theoretical probabilities. According to the law of large numbers, the probability of a large difference between the empirical probability and the theoretical limits to zero as more trials are collected (Stohl, 2005).

Through identifying the absence of these concepts within the ICoP in Egypt, the previously identified disconnection between the theoretical and experimental interpretation of probability within the Egyptian national textbooks in primary school that highlighted by Elbehary (2019) become more understandable; wherein the basic probabilistic idea which connects these two interpretations (i.e., the law of large numbers) has not been addressed within the ICoP. Besides, it also indicates how the indented curriculum impacts the potentially implemented curriculum (i.e., school textbooks), which have a high significance in the context of developing countries, and many teachers place priorities in discussing their activities. Consequently, simply following the current structure of national textbooks may affect students' understanding of probability in such a way of interpreting daily life probabilistic situations theoretically separated from the empirical results.

\section{CONCLUSION}

Although, the current study attempts to provide insight into the ICoP in Egypt from a comparative perspective, in such a way of informing the curriculum reform in the light of SDGs; there are some limitations should be taken into consideration to grasp the study results. For example, the study has addressed only two formal documents that have been shared on Egypt and New Zealand official websites. Besides, concerning the data analysis processes and issues of trustworthiness, there were some time constraints where only two months separate between the first and second analyzes.

Analyzing the intended curriculum that being declared in the official national documents provides a guiding statement for what a curriculum is intended to be in a specific context. The discussed ideas regarding the ICoP in Egypt and how it is consistent with the New Zealand curriculum, as an exemplar of well-defined statistics curriculum internationally, can be helpful for many practitioners. Curriculum developers who are in charge of revising and developing mathematics curriculum may need this information to look critically at the gaps and weakness points needed to be overcome to educate our children better. Notably, within the context of SDG strategy wherein developing the national curriculum to fit with the international context is one goal 
towards achieving quality education. Moreover, school curriculum investigation and teachers' own K-12 learning experiences have been identified as potential sources of teachers' knowledge (Stylianides \& Ball, 2004; Friedrichsen et al., 2009). Hence, the provided information is valuable for teacher educators to prepare prospective mathematics teachers, wherein these gaps of the curriculum can be addressed as a part of teacher education discussion. More precisely, on the one side, within a teaching situation, these results can cultivate prospective teachers' knowledge through strengthening their awareness towards various probabilistic misconceptions, which may appear later in their students. Besides, helping them to think of educational tasks and activities to provide the students with different opportunities to confront their misconceptions. For example, engaging them with substantial activities, in which the relationship between the classical and frequentist probability is highlighted (Sharma, 2016). On the other side, in their daily life situation, it is also crucial in interpreting multiple probabilistic situations, such as a medical test result (Borovcnik, 2008). Finally, studying the ICoP in Egypt supplies data about the basic probabilistic ideas that expected to learn. Therefore, investigating to what extent do these ideas (i.e., current instruction of probability) enhance students' probabilistic reasoning could be an expected schema for future research.

\section{Disclosure statement}

No potential conflict of interest was reported by the authors.

\section{Notes on contributors}

Samah Gamal Ahmed Elbehary - PhD Student at Graduate School for International Development and Cooperation, Hiroshima University, Japan and Assistant Lecturer at Faculty of Education, Tanta University, Egypt.

\section{REFERENCES}

Abdelbasit, K. M. (2010). Teaching Statistics in a Language Other Than the Students'. In C. Reading (Ed.), Data and Context in Statistics Education: Towards an Evidence Based Society. Proceedings of the Eighth International Conference on Teaching Statistics. Voorburg, The Netherlands: International Statistical Institute. Retrieved on 20 July 2019 from https://iaseweb.org/documents/papers/icots8/ICOTS8_C215_ABDELBASIT.pdf

Ainley, J., \& Monteiro, C. (2008). Comparing Curricular Approaches for Statistics in Primary School in England and Brazil: A Focus on Graphing. In C. Batanero, G. Burrill, C. Reading, \& A. Rossman (Eds.), Joint ICMI/IASE Study: Teaching Statistics in School Mathematics-Challenges for Teaching and Teacher Education. Proceedings of the ICMI Study 18 and 2008 IASE Round Table Conference. Retrieved on 20 July 2019 from https://iase-web.org/documents/papers/rt2008/T1P9_Ainley.pdf

Alfaki, I., \& Hijazi, R., (2018). Statistics Capacity Building and Alignment of Learning Outcomes with Business Sector Needs in the GSS Countries. In M. A. Sorto, A. White, \& L. Guyot (Eds.), Looking back, looking forward. Proceedings of the Tenth International Conference on Teaching Statistics (ICOTS10), Kyoto, Japan. Voorburg, The Netherlands: International Statistical Institute. Retrieved on 20 July 2019 from https://iase-web.org/icots/10/proceedings/pdfs/ICOTS10_C193.pdf

American Statistical Association. (2007). Guidelines for Assessment and Instruction in Statistics Education. Retrieved on 13 June 2019 from http://www.amstat.org/education/gaise/index.cfm

Batanero C., Chernoff E.J., Engel J., Lee H.S., \& Sánchez E. (2016). Research on Teaching and Learning Probability. In: Research on Teaching and Learning Probability. ICME-13 Topical Surveys. Springer, Cham. Retrieved on 9 July 2019 from https://ink. springer.com/chapter/10.1007/978-3-319-31625-3_1

Batanero, C., Biehler, R., Maxara, C., Engel, J., \& Vogel, M. (2005a). Using simulation to bridge teachers' content and pedagogical knowledge in probability. Paper presented at the fifteenth ICMI Study Conference: The professional education and development of teachers of mathematics. Aguas de Lindoia, Brazil: International Commission for Mathematical Instruction. Retrieved on 10 July 2019 from https://www.researchgate.net/publication/282281200_Using_simulation_to_bridge_teachers_content_ and_pedagogical_knowledge_in_probability

Batanero, C., Godino, J. D., \& Roa, R. (2004). Training teachers to teach probability. Journal of Statistics Education, 12(1). https://doi.org/10.1080/10691898.2004.11910715 
Batanero, C., Henry, M., \& Parzysz, B. (2005b). The nature of chance and probability. In G. A. Jones (Ed.), Exploring probability in school: challenges for teaching and learning (pp. 15-37). New York: Springer. https://doi.org/10.1007/0-387-24530-8_2

Beswick, K. (2007). Teachers' beliefs that matter in secondary mathematics classrooms. Educational Studies in Mathematics, 65(1), 95-120.

Borovcnik, M. (2008). A plea for a relatively strong role for probability within stochastic curricula. In C. Batanero, G. Burrill, C. Reading, \& A. Rossman (Eds.), Joint ICMI/IASE Study: Teaching Statistics in School Mathematics- Challenges for Teaching and Teacher Education. Retrieved on 20 June 2019 from https://www.stat.auckland.ac.nz/ iase/publications/rt08/Panel2_Borovcnik.pdf

Borovcnik, M., \& Kapadia, R. (2009). Research and Developments in Probability Education, International Electronic Journal of Mathematics Education, 4(3), 111-130. https://doi.org/10.1007/s10649-006-9035-3

Burrill, G., \& Biehler, R. (2011). Fundamental statistical ideas in the school curriculum and in training teachers. In: Batanero C., Burrill G., Reading C. (eds) Teaching Statistics in School MathematicsChallenges for Teaching and Teacher Education. New ICMI Study Series, vol 14. Springer, Dordrecht. https://doi.org/10.1007/978-94-007-1131-0_10

Carranza, P., \& Kuzniak, A. (2008). Duality of Probability and Statistics Teaching in French Education. In C. Batanero, G. Burrill, C. Reading, \& A. Rossman (Eds.), Joint ICMI/IASE Study: Teaching Statistics in School Mathematics-Challenges for Teaching and Teacher Education. Proceedings of the ICMI Study 18 and 2008 IASE Round Table Conference, ICMI and IASE, Monterrey.

Chaput B., Girard J. C., \& Henry M. (2011). Frequentist Approach: Modelling and Simulation in Statistics and Probability Teaching. In: Batanero C., Burrill G., \& Reading C. (eds) Teaching Statistics in School Mathematics- Challenges for Teaching and Teacher Education. New ICMI Study Series, vol 14. Springer, Dordrecht. https://doi.org/10.1007/978-94-007-1131-0_12

Chiesi, F., \& Primi, C. (2009). Recency effects in primary-age children and college students. International Electronic Journal of Mathematics Education, 4(3), 259-274.

Clark, S. S. (2010). Enacting Students to Use the Chi- Square Test when Observation Are Dependent. In C. Reading (Ed.), Proceedings of the Eighth International Conference on Teaching Statistics, Ljubljana, Slovenia. Voorburg, The Netherlands: International Statistical Institute. Retrieved on 7 July 2019 from http://icots.info/8/cd/pdfs/contributed/ICOTS8_C282_CLARK.pdf

Curriculum Center for Instructional Materials Development (CCIMD). (2012). Qualitative Documents for Basic Education. Retrieved on 20 May 2019 from http://moe.gov.eg/ccimd/Doc_quality $1 . h t m l$

David, I., \& Brown, J. A. (2010). Implementing the change: teaching statistical thinking not just methods. In C. Reading (Ed.), Data and context in statistics education: Towards an evidence-based society. Proceedings of the Eighth International Conference on Teaching Statistics (ICOTS8), Ljubljana, Slovenia. Voorburg, The Netherlands: International Statistical Institute.

David, I., Seddon, H., Harlow, J., \& Brown, J. (2014). Teaching Statistics in a Crisis Zone. In C. Reading (Ed.), Proceedings of the Eighth International Conference on Teaching Statistics, Ljubljana, Slovenia. Voorburg, The Netherlands: International Statistical Institute. Retrieved on 12 July 2019 from https://icots.info/9/proceedings/pdfs/ICOTS9_C137_DAVID.pdf

Downe-Wamboldt, B. (1992). Content analysis: Method, applications and issues. Health Care for Women International, 13(3), 313-321. https://doi.org/10.1080/07399339209516006

Edwards, H. (2014). A Review of Probability and Statistics APPS for Mobile Devices. In K. Makar, B. de Sousa, \& R. Gould (Eds.), Sustainability in statistics education. Proceedings of the Ninth International Conference on Teaching Statistics (ICOTS9), Flagstaff, Arizona, USA. Voorburg, The Netherlands: International Statistical Institute. Retrieved on 7 July 2019 from https:/iase-web.org/icots/9/ proceedings/pdfs/ICOTS9_C116_EDWARDS.pdf

Elbehary, S. (2019). The Necessity of Revising Primary School Content of Probability in Egypt to Enhance Students' Probabilistic Reasoning. In: S Budgett (Ed.), Decision Making Based on Data Proceedings of the Satellite conference of the International Association for Statistical Education (IASE), August 2019, Kuala Lumpur, Malaysia. Retrieved on 1 October 2019 from http://iase-web.org/documents/ papers/sat2019/IASE2019\%20Satellite\%20130_ELBEHARY.pdf?1569666566

Elo, S., Kääriäinen, M., Kanste, O., Pölkki, T., Utriainen, K., \& Kyngäs, H. (2014). Qualitative content analysis: A focus on trustworthiness. SAGE Open, 4(1), 1-10. https://oi.org/10.1177/2158244014522633 
Folger, J. P., Hewes, D. E., \& Poole, M. S. (1984). Coding social interaction. In B. Dervin, \& M. J. Voigt (Ed.), Progress in communication sciences (pp. 115-161). Norwood, NJ: Ablex.

Forbes, S. (2014). The coming of age of statistics education in New Zealand, and its influence internationally. Journal of Statistics Education, 22(2), 1-19. https://doi.org/10.1080/10691898.2014.11889699

Foster. M. (2018). Teaching Time Series to Undergraduate Students. In M. A. Sorto, A. White, \& L. Guyot (Eds.), Looking back, looking forward. Proceedings of the Tenth International Conference on Teaching Statistics (ICOTS10), Kyoto, Japan. Voorburg, The Netherlands: International Statistical Institute. Retrieved on 7 July 2019 from https://iase-web.org/icots/10/proceedings/pdfs/ICOTS10_C195.pdf? 1531364322

Friedrichsen, P. J., Abell, S. K., Pareja, E. M., Brown, P. L., Lankford, D. M., \& Volkmann, M. J. (2009). Does teaching experience matter? Examining biology teachers' prior knowledge for teaching in an alternative certification program. Journal of Research in Science Teaching, 46(4), 357-383. https://doi.org/10.1002/tea.20283

Godino, J. D., Batanero, C., \& Font, V. (2007). The onto-semiotic approach to research in mathematics education. ZDM. The International Journal on Mathematics Education, 39(1), 127-135. https://doi.org/10.1007/s11858-006-0004-1

Hacking, I. (1990). The Taming of Chance (Ideas in Context). Cambridge: Cambridge University Press. https://doi.org/10.1017/CB09780511819766

Heitele, D. (1975). An epistemological view on fundamental stochastic ideas. Educational Studies in Mathematics, 6(2), 187-205. https://doi.org/10.1007/BF00302543

Houang, R. T., \& Schmidt, W. H. (2008). TIMSS international curriculum analysis and measuring educational opportunities. Paper presented at 3 rd IEA International Research Conference (IRC 2008), Taiwan Normal University, Taipei. Retrieved on 1 July 2019 from http://citeseerx.ist.psu.edu/viewdoc/ download?doi=10.1.1.637.4062\&rep=rep1\&type=pdf

Hsieh, H.-F., \& Shannon, S. (2005). Three approaches to qualitative content analysis. Qualitative Health Research, 15(9), 1277-1288. https://doi.org/10.1177/1049732305276687

Innabi, H. (2014). Teaching statistics in the Arab countries: The ambitions and the needs. In K. Makar, B. de Sousa, \& R. Gould (Eds.), Sustainability in statistics education. Proceedings of the Ninth International Conference on Teaching Statistics (ICOTS9), Flagstaff, Arizona, USA. Voorburg, The Netherlands: International Statistical Institute. Retrieved on 5 July 2019 from https://iase-web.org/icots/9/ proceedings/pdfs/ICOTS9_C286_INNABI.pdf

Jones, G. A., Langrall, C. W., \& Mooney, E. S. (2007). Research in probability: responding to classroom realities. In F.K. Lester Jr. (Ed.), The second handbook of research on mathematics teaching and learning: A project of the National Council of Teachers of Mathematics (pp. 909- 955). Charlotte, NC: Information Age Publishing.

Kaid, L. L. (1989). Content analysis. In P. Emmert \& L. L. Barker (Eds.), Measurement of communication behavior (pp. 197-217). New York: Longman.

Kazak, S., \& Confrey, J. (2006). Elementary school students' informal and intuitive conceptions of probability and distribution. In A. Rossman, \& B. Chance (Eds.), Proceedings of the Seventh International Conference on Teaching Statistics, Salvador, Brazil: International Statistical Institute and International Association for Statistical Education. Retrieved on 20 August 2019 from https://iaseweb.org/documents/papers/icots7/6B1_KAZA.pdf

Kazima, M. (2007). Malawian students meaning for probability vocabulary. Educational Studies in Mathematics, 64(2), 169-189. https://doi.org/10.1007/s10649-006-9032-6

Kruger, L., Gigerenzer, G., \& Morgan, M. S. (Eds.). (1987). The Probabilistic Revolution: Ideas in the Sciences. Cambridge, MA: MIT Press.

Kurz, A. (2011). Access to what should be taught and will be tested: Students' opportunity to learn the intended curriculum. In S. N. Elliott, R. J. Kettler, P. A. Beddow, \& A. Kurz (Eds.), The handbook of accessible achievement tests for all students: Bridging the gaps between research, practice, and policy (pp. 99-129). New York: Springer. https://doi.org/10.1007/978-1-4419-9356-4_6

Martignon, L. (2014). Fostering children's probabilistic reasoning and first elements of risk evaluation In E. J. Chernoff, \& B. Sriraman (Eds.), Probabilistic thinking, presenting plural perspectives (pp. 149-160). Dordrecht: The Netherlands: Springer. https://doi.org/10.1007/978-94-007-7155-0_9 
Martin, M. O. (Ed.). (2005). TIMSS 2003 User Guide for the International Data Dase. TIMSS \& PIRLS International Study Center Lynch School of Education, Boston College. Retrieved on 14 June 2019 from https:/timss.bc.edu/timss2003i/PDF/t03_userguide.pdf

McTavish, D.-G., \& Pirro, E.-B. (1990). Contextual content analysis. Quality and Quantity, 24(3), 245-265. https://doi.org/10.1007/BF00139259

Mina, F. M. (2018). A suggested theoretical basis for teacher learning in statistics. In M. A. Sorto, A. White, \& L. Guyot (Eds.), Looking back, looking forward. Proceedings of the Tenth International Conference on Teaching Statistics (ICOTS10), Kyoto, Japan. Voorburg, The Netherlands: International Statistical Institute. Retrieved on 4 July 2019 from https://iase-web.org/icots/9/proceedings/pdfs/ICOTS9_C284_ MINA.pdf

Mullis, I. V. S., Martin, M. O., \& Foy, P. (with Olson, J.F., Preuschoff, C., Erberber, E., Arora, A., \& Galia, J.). (2008). Chestnut Hill, MA: TIMSS \& PIRLS International Study Center, Boston College. Retrieved on 14 June 2019 from https://timss.bc.edu/TIMSS2007/PDF/TIMSS2007_InternationalMathematics Report.pdf

Nacarato, A. M., \& Grando, R. C. (2014). The role of language in building probabilistic thinking. Statistics Education Research Journal, 13(2), 93-103.

National Council of Teachers of Mathematics. (2000). Principles and standards for school mathematics. Reston, VA: Author.

Paul, M., \& Hlanganipai, N. (2014). The nature of misconceptions and cognitive obstacles faced by secondary school mathematics students in understanding probability: A case study of selected Polokwane secondary schools. Mathematical Journal of Social Sciences, 5(8), 446-455.

Pecky. R. \& Gould, R. (2005). Preparing secondary teachers to teach statistics: A distance education model. Invited paper at the International Statistical Institute 55th Session, Sydney. Retrieved on 29 July 2019 from https://iase-web.org/documents/papers/isi55/Peck-Gould.pdf

Petty, N. W. (2010). Creating YouTube Videos that Engage Students and Enhance Learning in Statistics and Excel. In C. Reading (Ed.), Proceedings of the Eighth International Conference on Teaching Statistics, Ljubljana, Slovenia. Voorburg, The Netherlands: International Statistical Institute. Retrieved on 3 July 2019 from https://www.stat.auckland.ac.nz/ iase/publications/icots8/ICOTS8_C165_PETTY.pdf

Phaeton, M. J., \& Stears, M. (2017). Exploring the alignment of the intended and implemented curriculum through teachers' interpretation: A case study of A-level biology practical work. Eurasia Journal of Mathematics, Science \& Technology Education, 13(3), 723-740. https://oi.org/10.12973/eurasia.2017. 00640a

Polly, D. McGee, J. R., Wang, C., Richard G. L., David, K. P., \& Johnson, S. (2013). The association between teachers' beliefs, enacted practices, and student learning in mathematics. The Mathematics Educator, 22(2), 11-30.

Rubel, L. H. (2007). Middle school and high school students' probabilistic reasoning on coin tasks. Journal for Research in Mathematics Education, 38(5), 531-556.

Schreier, M. (2012). Qualitative content analysis in practice. Thousand Oaks, CA: Sage.

Sharma, S. (2014). Influence of culture on high school students' understanding of statistics: A Fijian perspective. Statistics Education Research Journal, 13(2), 104-117.

Sharma, S. (2016). Probability from a socio-cultural perspective. Statistics Education Research Journal, 15(2), 126-144.

Stein, M. K., \& Kim, G. (2009). The role of mathematics curriculum materials in large-scale urban reform: An analysis of demands and opportunities for teacher learning. In J. T. Remillard, B. A. HerbelEisenmann, \& G. M. Lloyd (Eds.), Mathematics teachers at work: Connecting curriculum materials and classroom instruction (pp. 37-55). New York: Routledge.

Steinbring, H. (1991). The theoretical nature of probability in the classroom. In R. Kapadia, \& M. Borovcnik (Eds.), Chance Encounters: Probability in Education, (pp. 135-167). The Netherlands: Kluwer Academic Publishers. https://doi.org/10.1007/978-94-011-3532-0_5 
Stern, D., Stirling, D., Dale., I., \& Stern, R. (2010). The Use of Computer- Based Tests to Consolidate Statistical Concepts in Kenya. In C. Reading (Ed.), Data and context in statistics education: Towards an evidencebased society. Proceedings of the Eighth International Conference on Teaching Statistics (ICOTS8), Ljubljana, Slovenia. Voorburg, The Netherlands: International Statistical Institute. Retrieved on 4 July 2019 from http://icots.info/8/cd/pdfs/contributed/ICOTS8_C173_STERN.pdf

Stohl, H. (2005). Probability in teacher education and development. In G. Jones (Ed.), Exploring probability in schools: Challenges for teaching and learning (pp. 345-366). New York: Springer. https://doi.org/10.1007/0-387-24530-8_15

Stylianides, A. J., \& Ball, D. L. (2004). Studying the mathematical knowledge needed for teaching: The case of teachers' knowledge of reasoning and proof. Paper presented at the 2004 Annual Meeting of the American Educational Research Association.

Sustainable Development Goals Knowledge Platform. (2019). States Members of the United Nations and States members of specialized agencies. Retrieved on 27 June 2019 from https://sustainabledevelopment.un.org/memberstates

Sustainable Development Strategy: Egypt Vision 2030. (2016). Retrieved on 20 June 2019 from http://sdsegypt2030.com/category/reports-en/page/2/?lang=en

Tesch, R. (1990). Qualitative research: Analysis types and software tools. Bristol, PA: Falmer.

The New Zealand Curriculum. (2007). Achievement Objectives by Learning Area. Retrieved on 9 August 2019 from http://nzcurriculum.tki.org.nz/The-New-Zealand-Curriculum

The Sustainable Development Goals Report. (2019). Retrieved on 23 August 2019 from https://unstats.un.org/sdgs/report/2019/

Thijs, A., \& van den Akker, J. (Eds.). (2009). Curriculum in development. Enschede, Netherlands: SLONetherlands Institute for Curriculum Development.

TIMSS \& PIRLS International Study Center. (2019). TIMSS 2019 Assessment Frameworks. Retrieved on 24 December 2018 from http://timss2019.org/wp-content/uploads/frameworks/T19-AssessmentFrameworks-Introduction.pdf

Torres, G.E., Contreras, J. M. (2014). Meaning of Probability in Spanish Curriculum for Elementary School. In K. Makar, B. de Sousa, \& R. Gould (Eds.), Sustainability in statistics education. Proceedings of the Ninth International Conference on Teaching Statistics (ICOTS9), Flagstaff, Arizona, USA. Voorburg, The Netherlands: International Statistical Institute. Retrieved on4 July 2019 from https://iaseweb.org/icots/9/proceedings/pdfs/ICOTS9_C143_GOMEZTORRES.pdf

Wang, D., Q. \& Wu, B. (2010). Compare Students' Attitudes to Learn Mathematics and Statistics in China and Australia. In C. Reading (Ed.), Proceedings of the Eighth International Conference on Teaching Statistics, Ljubljana, Slovenia. Voorburg, The Netherlands: International Statistical Institute. Retrieved on 5 July 2019 from http://icots.info/8/cd/pdfs/contributed/ICOTS8_C113_WANG.pdf

Zazkis, R., \& Chernoff, E. (2008). What Makes a Counterexample Exemplary? Educational Studies in Mathematics, 68(3), 195-208. https://doi.org/10.1007/s10649-007-9110-4 